Arq. Bras. Med. Vet. Zootec., v.62, n.1, p.136-143, 2010

\title{
Components of (co)variance of the days open in Siboney dairy cows
}

\author{
[Componentes de (co)variância dos dias vazios em vacas leiteiras Siboney] \\ D. González-Peña ${ }^{1}$, J.L. Espinoza-Villavicencio ${ }^{2 *}$, D. Guerra ${ }^{1}$, \\ A. Palacios ${ }^{2}$, J.C. Évora ${ }^{1}$, A. Portales ${ }^{1}$ \\ ${ }^{1}$ Centro de Investigaciones para el Mejoramento Animal de la \\ Ganadería Tropical - La Habana, Cuba \\ ${ }^{2}$ Departamento de Zootecnia - Universidad Autónoma de Baja California Sur \\ Carretera al sur, km 55, CP 23080 \\ La Paz - B.C.S., México
}

\begin{abstract}
The records of 63,406 calvings of Siboney dairy cows (5/8 Holstein 3/8 Cuban Zebu) were used to estimate the components of covariance of the days open (DO). Five models were used: of repeatability; univariate; bivariate; of random regression with Legendre polynomials and the parity number as predicting variable; and a model of random regression with Legendre polynomials and heterogeneity of the residual variance. The heritability obtained with the univariate model was 0.09 in the first calving and decreased to 0.05 in the fifth. A higher estimate of heritability (0.12) was obtained with the repeatability model. When the model of random regression with heterogeneity of the residual variance was used, the heritability was higher than the values estimated with the previous models. The genetic correlations among the DO in different calvings, estimated with the models of random regression with and without heterogeneity of the residual variance, were close to 1.0. It is concluded that the estimates of heritability increased with the use of the random regression models. The genetic correlations among the DO of different calvings indicated that in the first three, the DO are regulated for the most part by the same genes.
\end{abstract}

Keywords: dairy cow, genetic correlations, heritability, postpartum interval, days open

\section{RESUMO}

Os registros de 63.406 partos de vacas Siboney (5/8 Holstein 3/8 Cebu de Cuba) foram utilizados para estimar os componentes de (co)variância de dias vazios (DV). Utilizaram-se cinco modelos: de repetitividade; univariado; bivariado; de regressão aleatória com polinômios de Legendre e número de partos como variável preditiva; e de regressão aleatória com polinômios de Legendre e heterogeneidade da variância residual. A herdabilidade obtida com o modelo univariado foi de 0,09 no primeiro e diminuiu a 0,05 no quinto parto. Uma estimativa de herdabilidade mais alta $(0,12)$ foi obtida com o modelo de repetitividade. Quando foi usado o modelo de regressão aleatória com heterogeneidade da variância residual a herdabilidade foi superior aos valores estimados com os modelos anteriores. As correlações genéticas entre os DV em distintos partos, estimadas com os modelos de regressão aleatória com e sem heterogeneidade da variância residual, foram próximos a 1,0. Concluiu-se que as estimativas de herdabilidade foram incrementadas com o uso dos modelos de regressão aleatória. As correlações genéticas entre os $D V$ de diferentes partos indicaram que, nos três primeiros, os DV são regulados na sua maior proporção pelos mesmos genes.

Palavras-chave: gado de leite correlação genética, herdabilidade, intervalo pós-parto, período de serviço

Recebido em 12 de agosto de 2008

Aceito em 28 de dezembro de 2009

*Autor para correspondência (corresponding author)

E-mail: jlvilla@uabcs.mx 


\section{INTRODUCTION}

The interval between calving and pregnancy, also known as postpartum interval, service period or days open (DO) has been widely studied in some traditional breeds of dairy cattle (Oseni et al., 2004), given that they are related to the productive performance in the female and its economic profitability (Kirkpatrick, 1998). Furthermore, the time required to measure this characteristic is shorter than that needed to evaluate other reproductive traits such as calving interval (Goyache et al., 2005). Although it is true that the genetic progress of fertility requires a prolonged period of time due to its low values of heritability, the improvement of this trait can be achieved more rapidly if the DO are considered as a trait that indicates the onset of reproductive performance (González and Alenda, 2005). The genetic merit of the reproductive performance may change through time, given that there exists the possibility that different genes are expressed in distinct stages of the reproductive life of the cow (Schaeffer, 2004).

The traits that are measured repeatedly over time are known as longitudinal data or trajectory data (Hill and Brotherstone, 1999). This is the case of variables such as milk yield within a lactation, feed intake, or some reproductive characteristics (Schaeffer, 2004). This type of data has motivated interest among biometrists in recent years (Foulley et al., 2000), who have employed longitudinal designs for their analysis, whose advantage is the possibility of studying the individual changes over time.

Based on the above, the objective of the present study was to estimate the components of (co) variance of the days open in Siboney cattle of Cuba, using different mathematical models.

\section{MATERIAL AND METHODS}

The data for this study were obtained from the archives of the Centro Nacional de Control Pecuario (CENCOP) of the Republic of Cuba. The animals belong to 53 herds, property of the Empresa Nazareno, located in the province of Havana, Cuba, located at the entrance of the Gulf of Mexico, between parallels 20 and $23^{\circ} \mathrm{N}$ and meridians 74 and $85^{\circ} \mathrm{W}$. According to the classification of Köppen (modified), in most of Cuba the predominant climate is warm tropical.
There are two defined seasons, the dry season (winter) from November to April, and the rainy season (summer) from May to October. The mean annual temperature is $25^{\circ} \mathrm{C}$, the mean in winter is $20^{\circ} \mathrm{C}$, and 26 to $27^{\circ} \mathrm{C}$ in summer. The minimum temperatures vary between 1 and $8.5^{\circ} \mathrm{C}$ in the western part and between 3 and $12.5^{\circ} \mathrm{C}$ in the eastern part; the maximum temperatures recorded are between 36 and $38^{\circ} \mathrm{C}$. The average relative humidity is $80 \%$. The mean annual rainfall is $1200 \mathrm{~mm}$, with $30 \%$ in the winter period and $70 \%$ in summer. Rains are more abundant in the west than in the eastern part of the country (Institute..., 2006).

The initial sample of data was comprised of 63406 calvings occurring between 1977 and 2004 in Siboney cows (5/8 Holstein 3/8 Cuban Zebu) maintained under a program of artificial insemination at natural estrous. The feeding system was based on grazing by approximately $12 \mathrm{~h}$ daily. Cows were fed mainly Stars grass (Cynodon nlemfuensis) and Guinean grass (Panicum maximum), but during the rainy season, the cows were fed additional natural grass. Cows were milked twice a day, and during each milking they were fed $0.45 \mathrm{~kg}$ of concentrate per liter of milk from the fourth liter produced. In the afternoon, the animals were kept in the barn and fed cut forage such as king grass (Penisetum purpureum) and sugar cane (Saccharum officinarum).

The DO of each calving was calculated by subtracting the duration of gestation from the calving interval. The duration of the gestation was considered constant (285 days) for all of the calvings. For the analysis only the calving intervals that were within the range of 300 and 730 days were considered. The records of contemporary groups (herd-year of calvingcalving season) with less than 10 animals were eliminated. For the analysis, the parity was categorized in $1,2,3,4$, and $\geq 5$. It was established as a requirement for all of the animals to have at least one calving. The final file was comprised of 37917 records of 10550 females and 22832 individuals in the pedigree.

For the estimation of the components of (co) variance of the DO, the data were analyzed with five mathematical models, using the program ASREML of Gilmour et al. (1999). 
The first was a repeatability model matricially described as:

$\mathbf{y}=\mathbf{X b}+\mathbf{Z a}+\mathbf{W} \mathbf{p}+\mathbf{e}$, where:

$\mathbf{y}$ is the vector of observations in DO;

b is the vector of the fixed effects which contain the effect of herd-year-season and parity;

$\mathbf{a}$ is the vector of the random effects of the animal;

$\mathbf{p}$ is the vector of the random effects of the permanent environment corresponding to each animal;

$\mathbf{e}$ is the vector of the random residual effects; and $\mathbf{X}, \mathbf{Z}$ and $\mathbf{W}$ are matrices of incidence that relate the data to the fixed and random effects, and those of the permanent environment, respectively.
The second was a univariate model described matricially as:

$\mathbf{Y}=\mathbf{X b}+\mathbf{Z} \mathbf{a}+\mathbf{e}$, where:

$\mathbf{y}$ is the vector of the observations in DO;

$\mathbf{b}$ is the vector of the fixed effects which contain the effect of herd-year-season and parity;

$\mathbf{a}$ is the vector of the random effects of the animal;

$\mathbf{e}$ is the vector of the random residual effects; and $\mathbf{X}$ and $\mathbf{Z}$ are incidence matrices that relate the data to the fixed and random effects, respectively.

The third was a bivariate model (its principal objective is to estimate the genetic and residual correlations) matricially described as follows:

$\left[\begin{array}{l}y_{1} \\ y_{2}\end{array}\right]=\left[\begin{array}{cc}x_{1} & 0 \\ 0 & x_{2}\end{array}\right]\left[\begin{array}{l}b_{1} \\ b_{2}\end{array}\right]+\left[\begin{array}{cc}z_{1} & 0 \\ 0 & z_{2}\end{array}\right]\left[\begin{array}{l}a_{1} \\ a_{2}\end{array}\right]+\left[\begin{array}{l}e_{1} \\ e_{2}\end{array}\right]$, where:

$\mathbf{y}_{\mathbf{i}}=$ vector of the observations for the $\mathrm{i}$-th DO;

$\mathbf{b}_{\mathbf{i}}=$ vector of the fixed effects (herd-year of calving-season of calving) for the i-th DO;

$\mathbf{a}_{\mathbf{i}}=$ vector of the random effects of the animal for the i-th DO:

$\mathbf{e}_{\mathbf{i}}=$ vector of the random residual effects for the $\mathrm{i}$-th DO; and

$\mathbf{X}_{\mathbf{i}}$ and $\mathbf{Z}_{\mathbf{i}}$ are matrices of designs which relate the data to the fixed and random effects, respectively.

It is assumed that:

$\operatorname{var}\left[\begin{array}{l}a_{1} \\ a_{2} \\ e_{1} \\ e_{2}\end{array}\right]=\left[\begin{array}{cccc}g_{11} A & g_{12} A & 0 & 0 \\ g_{21} A & g_{22} A & 0 & 0 \\ 0 & 0 & r_{11} & r_{12} \\ 0 & 0 & r_{21} & r_{22}\end{array}\right]$, where:

$\mathbf{g}_{\mathbf{i j}}$ is the additive genetic variance of the $\mathrm{i}$-th DO, when $\mathrm{i}=\mathrm{j}$ and the genetic covariance when $\mathrm{i} \neq \mathrm{j}$;

$\mathbf{A}$ is the matrix of additive genetic relations; and

$\mathbf{r}_{\mathrm{ij}}$ is the variance when $\mathrm{i}=\mathrm{j}$ and the covariance when $\mathrm{i} \neq \mathrm{j}$.

Each DO was considered as an independent feature which is genetically and environmentally correlated with the others.

The fourth was a model of random regression, which used Legendre polynomials using parity as predictive variable. Based on previous analyses it was not considered necessary to include the effect of the permanent environment in the

$$
\mathrm{y}_{\mathrm{it}}=\mathrm{F}_{\mathrm{i}}+\sum_{m=0}^{k-1} \alpha_{i m} \mathrm{P}_{\mathrm{m}}(\mathrm{t})+\varepsilon_{i j} \text {, where: }
$$

$\mathbf{y}$ is the vector of the DO;

$\mathbf{F}$ is the vector of the fixed effects (group of contemporaries);

$\mathbf{P}_{\mathbf{m}}(\mathbf{t})$ is the second order regression function which describes the trajectory for the additive genetic random effects;

$\boldsymbol{\alpha}$ is a vector with three random regression coefficients per animal for the additive genetic effects;

$\mathbf{k}$ (order 2) is the order of the Legendre polynomial; and

$\varepsilon_{i j}$ is the effect of the error. model. A Legendre polynomial of second order normalized in the range of -1 to +1 is the one that best fit to the data. Consequently, the model used was as follows: 
The residual variance was assumed diagonal and constant through each calving.

The fifth was a random regression model with Legendre polynomials and heterogeneity of the residual variance. The terms were the same as in the fourth model, but in this case five classes of error were created corresponding to each DO from each calving.

\section{RESULTS AND DISCUSSION}

Table 1 shows the observed DO, grouped according to their duration in seven categories (percentages). As the parity increased, the DO decreased by an average of 36 days between the first and the fifth calving.

Table 1. Proportion of the days open (DO) in Siboney cows, evaluated, corresponding to distinct categories established according to their duration (days); mean, standard deviation (SD) and coefficient of variation $(\mathrm{CV})$, per parity

\begin{tabular}{lccccc}
\hline \multirow{2}{*}{ Categories (days) } & \multicolumn{5}{c}{ Parity } \\
\cline { 2 - 6 } & 1 & 2 & 3 & 4 & 5 \\
\hline$\leq 90$ & 35.0 & 41.2 & 45.1 & 45.0 & 42.7 \\
91 a 120 & 14.2 & 16.1 & 15.1 & 15.1 & 19.6 \\
121 a 150 & 11.8 & 10.8 & 10.6 & 9.6 & 9.6 \\
151 a 180 & 8.2 & 8.1 & 7.2 & 6.4 & 6.6 \\
181 a 210 & 6.3 & 5.8 & 5.0 & 5.6 & 5.3 \\
211 a 240 & 5.4 & 4.2 & 3.8 & 4.1 & 4.8 \\
$\geq 241$ & 18.7 & 13.3 & 12.9 & 13.9 & 11.1 \\
Mean (days) & 152.2 & 134.4 & 129.5 & 122.1 & 116.1 \\
SD (days) & 58.1 & 82.4 & 81.0 & 80.1 & 73.6 \\
CV (\%) & 61.3 & 60.5 & 58.1 & 58.1 & 51.4 \\
Total of DO evaluated & 10550 & 8145 & 6138 & 4448 & 8636 \\
\hline
\end{tabular}

The means for DO observed in the present study agree with those reported by Abdallah and McDaniel (2000) in Holstein cows and by Heins et al. (2006) in Holstein and crossbreds of Holstein with European breeds. They are lower than the DO obtained by Dematawewa and Berger (1998) in Holstein cattle (169 days), and They are higher than those reported by EstradaLeón et al. (2008) in Brown Swiss cows (87.9 days).

The values of the coefficient of variation observed (51.4 to $61.3 \%$ ) indicate the variability of the trait, which is highly influenced by environmental factors, principally those related to herd management (Cavalcante et al., 2001). In Figure 1 it is observed that the additive genetic variance of the DO in each one of the calvings, estimated with the random regression model, is high.

The highest value was expressed in the first calving (1718) and the lowest (1078) in the fifth. These high values of the additive genetic variance led to similar tendencies of heritability. These results are affected by the residual variance (6364), because due to the characteristics of the model, it maintained constant throughout all of the calvings. The additive genetic variance of the random regression model with heterogeneity of the residual variance behaved in a similar manner to that of the previous model, with the difference that its highest value was 1542 units and the lowest, 872. In general terms, its curve was maintained with an average of 20 units below the one obtained with the random regression model. Although the random regression model that used the heterogeneity of the residual variance showed a reduction of the additive genetic variances, the values obtained are above the range of 34 to 549 reported in the literature (Oseni et al., 2004).

The residual variances obtained in the present study varied between 6113 and 6815. These results are high compared with the estimations of Hoeschele (1991), but do not reach the value of 9981 reported by Campos et al. (1994).

Figure 2 shows the heritability values for DO estimated with four different models. 


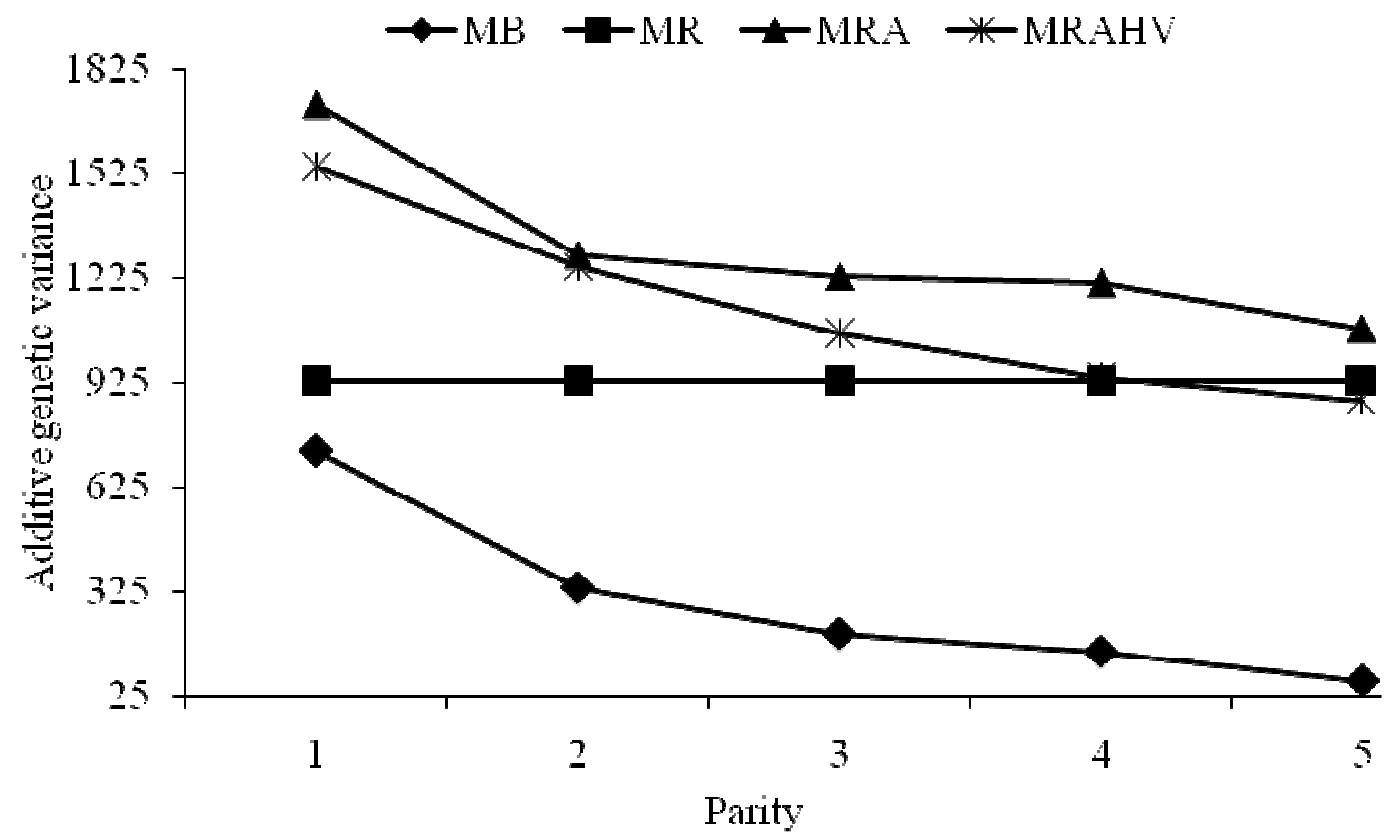

Figure 1. Estimates of additive genetic variance for the days open in Siboney cows using a univariate model (MU), a repeatability model (MR), a random regression model (MRA) or of random regression with heterogeneity of the residual variance (MRAHV).

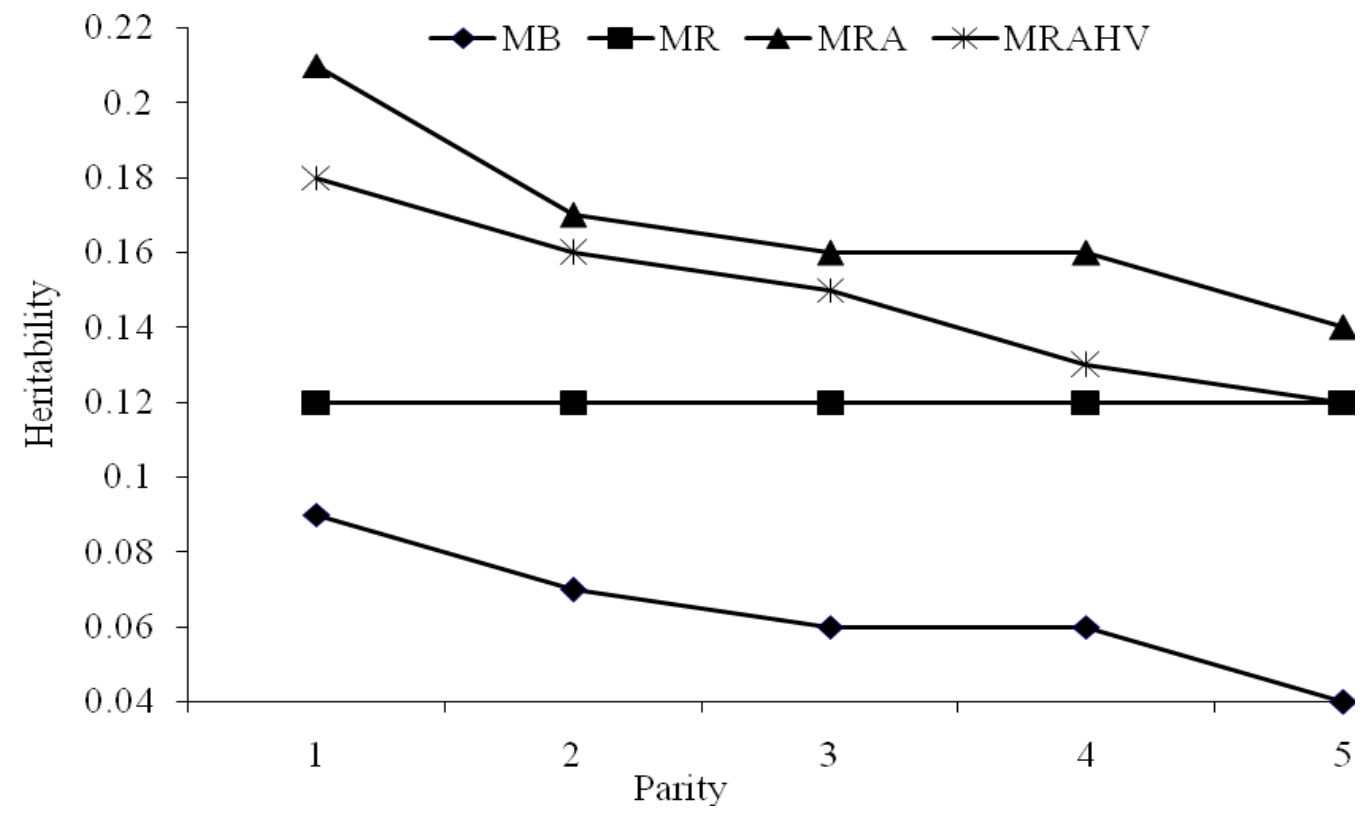

Figure 2. Estimates of heritability for the days open in Siboney cows using a univariate model (MU), a repeatability model (MR), a random regression model (MRA) or of random regression with heterogeneity of the residual variance (MRAHV). 
The heritability obtained with the univariate model was 0.09 in the first calving and gradually decreased to 0.05 in the fifth calving. An estimate of heritability higher than the above $(0.12)$ figures was obtained with the repeatability model. However, when the random regression model was used with heterogeneity of the residual variance; the heritability was much higher than that estimated with the previous models, and similarly, was reduced from the first to the fifth calving $(0.18,0.17,0.15,0.13$, and 0.12 , respectively). The highest heritabilities were obtained with the model of random regression with homogeneity of the residual variance. This is a logical result, given that the information from intervals where the residual variance is higher than the assumed homogeneous variance, may cause overestimation or subestimation of the genetic parameters (Rekaya et al., 2001). This model estimated heritabilities of 0.21 in the first calving and a reduction in the successive calvings $(0.17$, $0.16,0.16$, and 0.14 from the second to the fifth). This reduction is congruent with some reports of the literature which indicate that certain traits associated with fertility in heifers had a higher heritability than in adult cows (Muir et al., 2004).

The results obtained with the application of the univariate model are found within the range outlined by the literature, given that in general, heritabilities have been reported for DO in dairy cattle that fluctuate between 0.03 and 0.09 (González and Alenda, 2005; Chang et al., 2006; Estrada-León et al., 2008). Oseni et al. (2004), using different criteria for the edition of the information, estimated heritabilities between 0.03 and 0.06 for DO in Holstein cattle. Only some reports refer to heritabilities lower than 0.03 (Kadarmideen et al., 2003; AndersenRanberg et al., 2005a).

The low values of heritability generally reported for DO indicate that the environmental effects are more important than the additive genetic effects; however, these effects are sufficient to allow an effective selection (Weigel and Rekaya, 2000). When the repeatability model was used, an increase of heritability was observed with respect to the univariate model. This coincides with what was reported by Jamrozik et al. (2005), who point out that trait measurements such as time intervals have higher heritabilities than the characteristics of a binary or categorical nature. The contribution of the permanent environment (0.0018) over the DO in the present study was low.

The genetic $\left(\mathbf{r}_{\mathrm{g}}\right)$ and environmental correlations $\left(\mathbf{r}_{\mathbf{e}}\right)$ among the DO for the different calvings are shown in Table 2.

Table 2. Genetic correlations (above the diagonal) and environmental correlations (below the diagonal) among the days open in each calving

\begin{tabular}{cccccc}
\hline & \multicolumn{5}{c}{ Parity } \\
\cline { 2 - 6 } & 1 & 2 & 3 & 4 & 5 \\
\hline 1 & $\mathbf{1 . 0 0}$ & 0.99 & 0.99 & 0.80 & 0.65 \\
2 & 0.04 & $\mathbf{1 . 0 0}$ & 0.99 & 0.96 & 0.79 \\
3 & 0.04 & 0.04 & $\mathbf{1 . 0 0}$ & 0.99 & 0.75 \\
4 & 0.02 & 0.04 & 0.07 & $\mathbf{1 . 0 0}$ & 0.85 \\
5 & 0.02 & 0.02 & 0.06 & 0.10 & $\mathbf{1 . 0 0}$ \\
\hline
\end{tabular}

The $\mathbf{r}_{\mathrm{g}}$ among the DO of the first three calvings almost reached the unit. This could indicate that the DO in the first three calvings are regulated by the same genes, but does not occur in the same way for the later calvings. Goyache et al. (2005) found in the Asturiana de los Valles beef cattle breed, a genetic correlation of 1.0 among DO of the heifers and of the adult cows, suggesting that the DO were genetically the same trait independently of the parity. In contrast, Jansen et al. (1987) suggested that in dairy cattle, different genes can be expressed for DO in the different calvings, given that the genetic correlations estimated among the DO of calvings 1, 2 and 3 were not higher than 0.67. Roxström et al. (2001) and Andersen-Ranberg et al. (2005b) found relatively high correlations (0.54 to 0.67$)$ among fertility in heifers and cows of first calving. However, because the correlations are lower than 1.0 , the two traits are probably not genetically the same (Jamrozik et al., 2005). The values of the environmental correlations shown in Table 2 
indicate that the factors that influence over the DO in the different calvings of the Siboney cows are different.

The estimated values of the genetic correlations for DO with the random regression models with and without heterogeneity of the residual variance (Table 3) were close to 1.0 in all of the calvings, with the exception of the correlation between calving 1 and 5 . These genetic correlations coincide with the highest values of heritability obtained with the models of random regression.

Table 3. Genetic correlations among the days open in Siboney cows, estimated with a random regression model that used Legendre polynomials throughout the calvings (above the diagonal) and a random regression model with Legendre polynomials and heterogeneity of the residual variance (below the diagonal)

\begin{tabular}{llllll}
\hline & \multicolumn{5}{c}{ Parity } \\
\cline { 2 - 5 } & 1 & 2 & 3 & 4 & 5 \\
\hline 1 & $\mathbf{1 . 0 0}$ & 0.99 & 0.95 & 0.92 & 0.86 \\
2 & 0.99 & $\mathbf{1 . 0 0}$ & 0.99 & 0.96 & 0.90 \\
3 & 0.97 & 0.98 & $\mathbf{1 . 0 0}$ & 0.96 & 0.91 \\
4 & 0.92 & 0.94 & 0.97 & $\mathbf{1 . 0 0}$ & 0.98 \\
5 & 0.85 & 0.89 & 0.93 & 0.96 & $\mathbf{1 . 0 0}$ \\
\hline
\end{tabular}

\section{CONCLUSIONS}

The heritability estimated for DO with the univariate and repeatability models, from the first to the fifth calving in Siboney cattle, does not differ from the results found for this trait in other dairy breeds. The estimates of heritability increased with the use of the random regression models. The genetic correlations among the DO of different calvings indicated that in the first three, the DO are regulated in the most part by the same genes.

\section{REFERENCES}

ABDALLAH, J.M.; McDANIEL, B.T. Genetic parameters and trends of milk, fat, days open and body weight after calving in North Carolina experimental herds. J. Dairy Sci., v.83, p.13641370,2000

ANDERSEN-RANBERG, I.M.; HERINGSTAD, B.; GIANOLA, D. et al. Comparison between bivariate models for 56-day nonreturn and interval from calving to first insemination in Norwegian Red. J. Dairy Sci., v.88, p.2190-2198, 2005a.

ANDERSEN-RANBERG, I.M.; KLEMETSDAL, G.; HERINGSTAD, B. et al. Heritabilities, genetic correlations, and genetic change for female fertility and protein yield in Norwegian dairy cattle. $J$. Dairy Sci., v.88, p.348-355, 2005b.
CAMPOS, M.S.; WILCOX, C.J.; BECERRIL, C.M. et al. Genetic parameters for yield and reproductive traits of Holstein and Jersey cattle in Florida. J. Dairy Sci., v.77, p.867-873, 1994.

CAVALCANTE, F.A.; FILHO, R.M.; CAMPELLO, C.C. et al. Período de serviço em rebanho Nelore na Amazônia oriental. R. Bras. Zootec., v.30, p.1456-1459, 2001.

CHANG, Y.M.; ANDERSEN-RANBERG, I.M.; HERINGSTAD, B. et al. Bivariate analysis of number of services to conception and days open in Norwegian Red using a censored threshold-linear model. J. Dairy Sci., v.89, p.772-778, 2006.

DEMATAWEWA, C.M.; BERGER, P.J. Genetic and phenotypic parameters for 305-d yield, fertility and survival in Holsteins. J. Dairy Sci., v.81, p.2700-2709, 1998.

ESTRADA-LEÓN, R.J.; MAGAÑA， J.G.; SEGURA-CORREA, J.C. Genetic parameters for reproductive traits of Brown Swiss cows in the tropics of Mexico. J. Anim. Vet. Adv., v.7, p.124129, 2008.

FOULLEY， J.L.; JAFFRÉZIC， F.; ROBERTGRANIÉ, C. EM-REML estimation of covariance parameters in Gaussian mixed models for longitudinal data analysis. Genet. Sel. Evol., v.32, p.129-141, 2000. 
GONZÁLEZ, R.O.; ALENDA, R. Genetic parameters for female fertility traits and a fertility index in Spanish dairy cattle. J. Dairy Sci., v.88, p.3282-3289, 2005.

GOYACHE, F.; GUTIÉRREZ, J.P.; FERNÁNDEZ, I. et al. Genetic analysis of days open in beef cattle. Livest. Prod. Sci., v.93, p.283289, 2005.

GILMOUR, A.R.; CULLIS, B.R.; ERLHAM, S.J. et al. ASREML Reference Manual. Australia: NSW Agriculture, 1999.

HEINS, B.J.; HANSEN, L.B.; SEYKORA, A.J. Fertility and survival of pure Holsteins versus crossbreds of Holstein with Normande, Montbeliarde, and Scandinavian Red. J. Dairy Sci., v.89, p.4944-4951, 2006.

HILL, W.G.; BROTHERSTONE, S. Advances in methodology for utilizing sequential records. In: OLDHAM, J.D.; SIMM, G.; GROEN, A.F. et al. (Eds). Metabolic stress in dairy cows. Edinburgh: British Society of Animal Science (occasional publication, 24), 1999. p.55-61.

HOESCHELE, I. Additive and non-additive genetic variances in female fertility of Holsteins. J. Dairy Sci., v.74, p.1743-1752, 1991.

INSTITUTO Meteorológico de la República de Cuba (IMRC), 2006. Disponible en: $<$ http://www.cubasolidarity.net/infomed/www.met.i nf.cu/default.htm>. Acessado em: 4 out. 2006.

JAMROZIK, J.; FATEHI, J.G.; KISTEMAKER, J. et al. Estimates of genetic parameter for Canadian Holstein female reproduction traits. J. Dairy Sci., v.88, p.2199-2208, 2005.

JANSEN, J.; VAN DER WERF, J.; DE BOER, W. Genetic relationships between fertility traits for dairy cows in different parities. Livest. Prod. Sci., v.17, p.337-349, 1987.
KADARMIDEEN， H.N.; THOMPSON， R.; COFFEY, M.P. et al. Genetic parameters and evaluations from single and multiple trait analysis of dairy cow fertility and milk production. Livest. Prod. Sci., v.81, p.183-195, 2003.

KIRKPATRICK, B.W. Genetics and biology of reproduction in cattle. In: FRIES, R.; RUVINSKY, A. (Eds). The genetics of cattle. 3.ed. Wallingford, UK: CAB International, 1998. p.391-410.

MUIR, B.L.; FATEHI, J.; SCHAEFFER. L.R. Genetic relationships between persistency and reproductive performance in first-lactation Canadian Holsteins. J. Dairy Sci., v.87, p.30293037, 2004.

OSENI, S.; TSURUTA, S.; MISZTAL, I. et al. Genetic parameters for days open and pregnancy rates in US Holsteins using different editing criteria. J. Dairy Sci., v.87, p.4327-4333, 2004.

REKAYA, R.; WEIGEL, K.A.; GIANOLA, D. Hierarchical nonlinear models for the persistency of milk yields in the first three lactations of Holsteins. Livest. Prod. Sci., v.68, p.181-187, 2001.

ROXSTRÖM, A.; STRANDBERG, E.; BERGLUND, B. et al. Genetic and environmental correlations among female fertility traits and milk production in different parities of Swedish Red and White Dairy Cattle. Acta Agric. Scand. A, v.51, p.714, 2001.

SCHAEFFER, L.R. Application of random regression models in animal breeding. Livest. Prod. Sci., v.86, p.35-45, 2004.

WEIGEL, K.A.; REKAYA, R. Genetic parameters for reproductive traits of Holstein cattle in California and Minnesota. J. Dairy Sci., v.83, p.1072-1080, 2000. 